\title{
The disappearing exostosis?
}

\section{A report of an unusual case}

\author{
G. Capasso ${ }^{1}$, V. Testa ${ }^{2}$, N. Maffulli ${ }^{3}$ \\ ${ }^{1}$ Instituto di Clinica Ortopedica, Seconda Università degli Studi Napoli, Via S Andrea delle Dame 4, Napoli, Italy \\ 2 Dynamic Center, Via della Rebubblica 7, Angri (Sa), Italy \\ ${ }^{3}$ Department of Orthopaedics and Traumatology, The Chinese University of Hong Kong, Prince of Wales Hospital, Shatin, NT, \\ Hong Kong
}

Accepted: 22 February 1997

Summary. A girl aged 11 years was referred to us with a medial upper right tibial exostosis. As the lesion was asymptomatic, surgery was not undertaken. The patient defaulted from follow up, and, when reviewed 32 months later, there was no clinical or radiographic evidence of the exostosis. Spontaneous involution of an exostosis may occasionally occur in childhood.

Résumé. Nous rapportons l'observation, d'une jeune fille de 11 ans qui presentait une néoformation au niveau de la métaphyse proximale $d u$ tibia droit, avec les caracteristiques cliniques et radiographiques d'une exostose sessile. Cette néoformation était asymptomatique et ne fut pas operée: on a conseillé des controles periodiques seulement. Après 32 mois il n'y avait plus aucune trace de cette exostose au controle clinique et radiographique. On peut penser à une involution spontanée de la néoformation, compte tenu de l'âge de cette fille.

\section{Introduction}

The clinical features and management of exostoses are well documented $[5,13]$. We present details of a girl in whom spontaneous involution took place.

Reprint requests to: G. Capasso, Via V Emanuele III, 50, I-80027 Frattamaggiore (Na), Italy

\section{Case report}

A girl aged 11 years was referred to us with a firm swelling at the proximal third of the right tibia. It was adherent to the deep tissues, approximately $2 \mathrm{~cm}$ in diameter, and neither painful nor tender. The child was otherwise clinically normal; in particular, no similar lesions were found on palpation of the skeleton and no limb length discrepancy was present. Plain radiography revealed a typical metaphyseal exostosis $[1,5,13]$ (Figs. 1,2). There was no family history of similar lesions. Surgical excision was suggested if pain [16] or other complications developed $[6-9,17]$. The parents delayed their decision; the child did not complain of any further symptoms, and the parents did not seek a further consultation.

After 32 months, a radiograph of the knee was taken by the patient's general practitioner: no trace of the exostosis was seen. The child was again referred to us. Clinically, no mass was palpable, and no scars were present. Radiography of both knees were normal.

The girl was seen again 33 months later, at which time her knees were clinically and radiographically normal (Fig. 3). A high resolution real time ultrasound scan [11] showed nonspecific soft tissue swelling overlying normal cortical bone (Fig. 4). The patient and her parents refused a biopsy, and the girl now remains well after a further 12 months.

\section{Discussion}

In our patient the exostosis was completely reabsorbed, and the upper right tibia regained its normal appearance within a 32 month period. We have no explanation of this phenomenon and despite an extensive literature search, we found only a few similar instances of disappearing exostoses $[2-4,12,14,15]$.

Detachment of an exostosis has been described [10]. In this instance, it was detected radiographically, and it was found as a loose body at operation. There is nothing to suggest that this process occurred in our patient but we are unable 

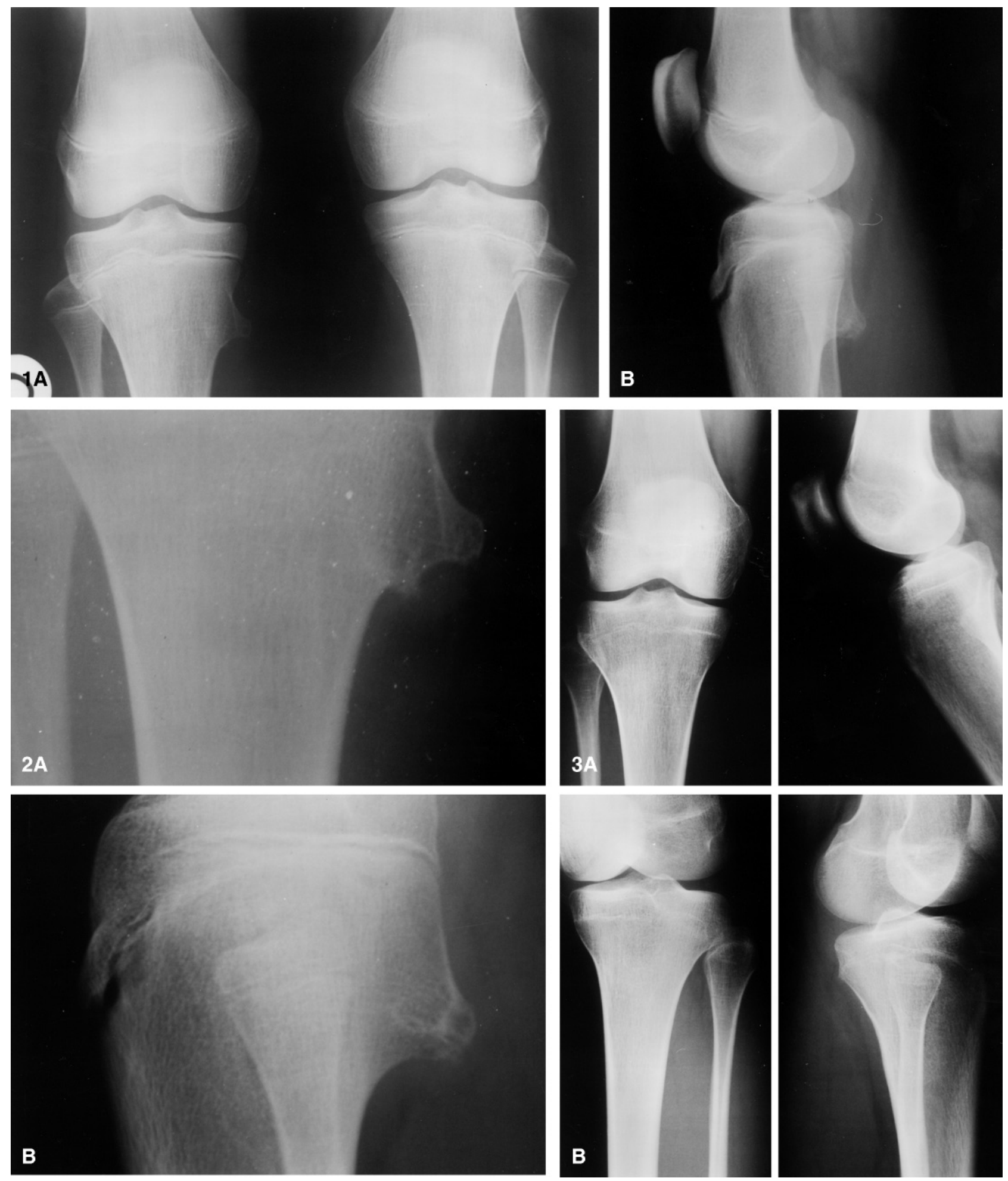

Fig. 1. A Anteroposterior radiograph of the knees. In the right knee a lesion which is rounded and approximately $4 \mathrm{~cm}$ in diameter protrudes from the tibial metaphysis on a pedunculated bony stalk. The cortex and spongiosa blend imperceptibly with the cortex and spongiosa of the host bone. The left knee is normal. B Lateral radiograph of the right knee. A typical metaphyseal exostosis is evident
Fig. 2A, B. Radiographs of the exostosis

Fig. 3A, B. Follow-up over 65 months confirms no radiographical evidence of exostosis 


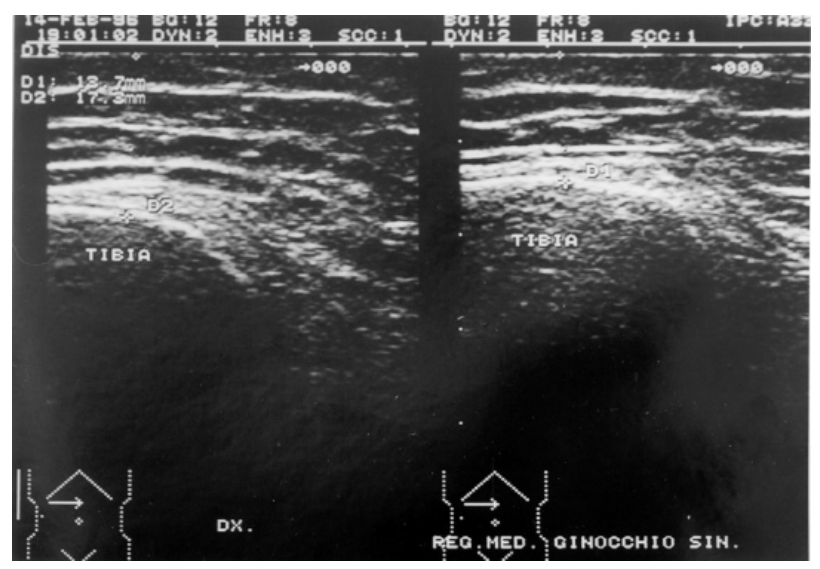

Fig. 4. A high resolution real time ultrasound scan shows nonspecific soft tissue swelling of the right leg (A) overlying normal cortical bone. Left leg (B) is normal

to explain the mechanism of resolution of the exostosis.

\section{References}

1. Black B, Dooley J, Pyper A, Reed M (1993) Multiple hereditary exostoses. An epidemiologic study of an isolated community in Manitoba. Clin Orthop 287: 212-217

2. Callan JE, Wood VE (1975) Spontaneous resolution of an osteochondroma. J Bone Joint Surg [Am] 57: 723

3. Castriota-Scanderberg A, Bonetti MG, Cammisa M, Dallapiccola B (1995) Spontaneous regression of exostoses: two case reports. Pediatr Radiol 25: 544-548
4. Copeland MR, Meehan PL, Morrissy RT (1985) Spontaneous regression of osteochondromas. J Bone Joint Surg [Am] 67: 971-973

5. Dahlin DC (1978) Bone tumors, 3rd edn. Thomas, Springfield, Illinois, pp 17-27

6. Dendale J, Amran S, Dermaker S, Guillaud R, Lesbros D (1995) Une rare complication des exostoses multiples: hemothoraxé. Arch Pediatr 2: 548-550

7. Eaton BA, Kettner NW, Essman JB (1995) Solitary osteochondroma of the cervical spine. J Manipul Physiol Ther 18: 250-253

8. Khaira HS, Parnell A, Crowson MC (1995) Femoral exostosis presenting with deep osteochondroma of the vein and arterial thrombosis. Br J Surg 82: 911-915

9. Lieberman J, Mazzucco J, Kwasnik E, Loyer R, Knight D (1994) Popliteal pseudoaneurysm as a complication of an adjacent osteochondroma. Ann Vasc Surg 8: 198-203

10. Low CK, Mitra AK, Balachandran N (1995) Exostosis presenting as solitary loose body in the ankle of two children. Ann Acad Med Singapore 24: 455-458

11. Malghem J, Vande-Berg B, Noel H, Maldague B (1992) Benign osteochondromas and exostostotic chondrosarcomas.. evaluation of cartilage cap thickness by ultrasound. Skeletal Radiol 21: 33-37

12. Merle P, Rougier JL, Duclos AM, Gras JC (1980) Exostoses èvanescente. J Radiol 61: 291-292

13. Mirra JM (1980) Bone tumors. Diagnosis and treatment. Lippincot, Philadelphia, pp 524-530

14. Pahling MR (1983) The "disappearing" osteochondroma. Skeletal Radiol 10: 40-42

15. Shaw BA (1996) Resolving neonatal osteochondroma. Am J Orthop 25: 226

16. Vanden-Maren C, Guillaumie B, Huge J, Bodart A, Van Ruyssevelt C (1994) Osteocondrome de la clavicule et épaule douloreuse. Rev Chir Orthop 80: 334-337

17. Witthaut J, Steffens KJ, Koob E (1994) Intermittent axillary nerve palsy caused by humeral exostosis. J Hand Surg (Br) 19: 422-423 